\title{
Discovery of isolated populations of Phengaris alcon and of Melitaea diamina in the central Po Plain, Italy \\ (Lepidoptera Rhopalocera)
}

\begin{abstract}
Riassunto - Scoperta di popolazioni isolate di Phengaris alcon $e$ Melitaea diamina nella Pianura Padana centrale (Italia) (Lepidoptera Rhopalocera). All'interno del Parco del Mincio (Mantova, Lombardia) sono state scoperte popolazioni di Melitaea diamina (Lang, 1789) e Phengaris alcon ([Denis \& Schiffermüller], 1775) (Lepidoptera Rhopalocera), rispettivamente nell'anno 2008 e 2010. Entrambe le specie non sono note per la Pianura Padana, e le popolazioni più vicine conosciute si trovano a 170 e $50 \mathrm{~km}$, rispettivamente per $P$. alcon e $M$. diamina. Durante l'anno 2011 sono state svolte ulteriori indagini su queste nuove popolazioni. Entrambe le specie sono state riscontrate esclusivamente in prati umidi, di cui sono considerate specie tipiche. Le nuove popolazioni dovranno essere protette, garantendo il mantenimento in futuro dei prati umidi mediante sfalcio.
\end{abstract}

\begin{abstract}
Populations of Melitaea diamina (Lang, 1789) and Phengaris alcon ([Denis \& Schiffermüller], 1775) (Lepidoptera Rhopalocera) were discovered in the Mincio Natural Park (Mantua province, Lombardy) in the years 2008 and 2010, respectively. Both species had not been known from the central Po Plain and the closest populations are approximately $170 \mathrm{~km}$ and $50 \mathrm{~km}$ away for P. alcon and M. diamina, respectively. More data on the new populations were collected during the year 2011. Both species were exclusively found in wet meadows, for which they are considered typical. The newly discovered populations need to be protected by ensuring that the meadows will continue to be mown in the future.
\end{abstract}

Key words: Lepidoptera, Phengaris alcon, Melitaea diamina, Italy, river Po Plain.

\section{INTRODUCTION}

The distribution of the Italian butterflies is generally well known (Balletto et al., 2005a), but new and important discoveries, which extend the known geographic range of species, are regularly reported (e.g. Sala \& Bettini, 2000; Rallo \& Uliana, 2001; Pensotti, 2004; Negrisolo \& Uliana, 2006; Bertaccini, 2008). This also applies to the Po Plain (e.g. Camerini \& Groppali, 2003; D’Amico, 2005), which represents the most strongly industrialized and densely populated area of Northern Italy. In the years 2008 and 2010 single individuals of the species Phengaris alcon ([Denis \& Schiffermüller], 1775) and Melitaea diamina (Lang, 1789), two species which are listed in the European Red List of Butterflies (Van Swaay et al., 2010), were discovered in the Mincio Natural Park (Mantua province, Italy). Phengaris alcon (Alcon Blue, Fig. 1) was not known from the Po Plain (e.g. Wynhoff, 1998; Lafranchis, 2004, Tolman \& Lewington, 2009, Balletto et al., 2005a; Villa et al., 2010) and is considered "near threatened" in the countries of the European Union (Van Swaay et al., 2010). Melitaea diamina (False Heat Frittilary, Fig. 2) was not known from the central Po Plain (Lafranchis, 2004; Balletto et al., 2005a; Tolman \& Lewington, 2009) and is considered "near threatened" in the countries of the European Union (Van Swaay et al., 2010).

The aim of this work is to document the newly discovered populations of $P$. alcon and $M$. diamina, to provide some indications on local populations and to discuss the discovery from a biogeographical and conservational point of view.

\section{Material AND MEthods}

Study AREA. The Mincio Natural Park, established by Regional Law 47/84, is situated in the Mantua province (Lombardy Region), and protects mainly areas along the river Mincio, for a total extension of 15.942 ha (Fig. 3). Here P. alcon was found in sites belonging to Molinia meadows on calcareous, peaty or clay-siltladen soils (Molinion caeruleae (L) Moench.) (Habitat 6410, Habitats Directive). From a phytosociological point of view, habitat 6410 coincides with the SelinoMolinietum caeruleae Kuhn 1937 association.

Study SPECIES. Here, $P$. alcon is considered as a species, as it has been done by many authors (e.g. Balletto et al., 2005; Küer \& Fartmann, 2005; Villa et al., 2010), even though recent studies suggest that $P$. alcon, and $P$. rebeli (Hirsche, 1904) are ecologic forms 


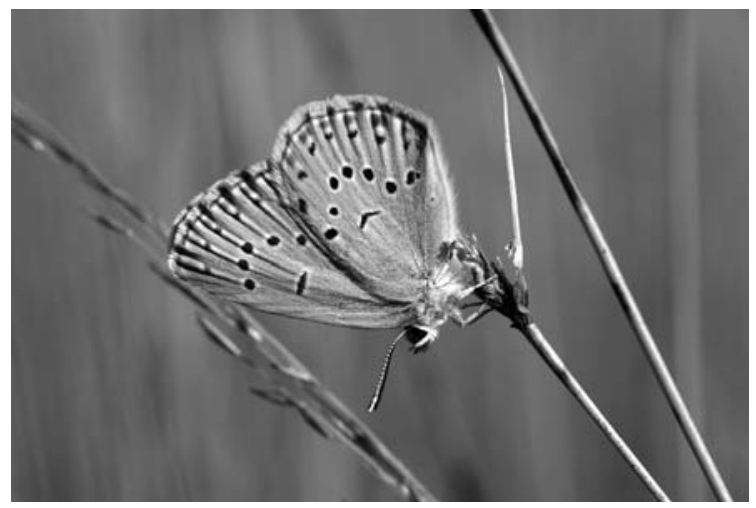

Fig. 1. Phengaris alcon ([Denis \& Schiffermüller], 1775). Photo by S. Hardersen.

of the same species (Als et al., 2004; Bereczki et al., 2005; Pecsenye et al., 2007; Descimon \& Mallet, 2009) and that the case of $P$. alcon and P. rebeli is the closest to "ecological races" (Descimon \& Mallet, 2009). Morphologically, P. alcon and P. rebeli are almost indistinguishable (Leigheb, 1990), and this also applies to larvae and pupae (Śliwińska et al., 2006) and recent studies did not find relevant differences at the genetics level (Als et al., 2004; Bereczki et al., 2005; Pecsenye et al., 2007; Descimon \& Mallet, 2009). The population described in this paper has been attributed to $P$. alcon based on ecological and phenological characteristics (e.g. habitat, host plant and phenology), as these are the most important traits to distinguish the two species (Sielezniew \& Stankiewicz, 2004).

The Alcon Blue is a hygrophilous species of lowlands and hills, which lives in wet meadows and marshes below 1000 m a.s.l. (Leigheb, 1990; Hellmann \& Bertaccini, 2004; Küer \& Fartmann, 2005; Varga-Sipos \& Varga, 2005; Villa et al., 2010). Its main host-plant is Gentiana pneumonanthe L. (Bereczki et al., 2005; Küer \& Fartmann, 2005; Śliwińska et al., 2006; Pecsenye et al., 2007; Villa et al., 2010), but other species from the genus Gentiana have also been reported (Munguira \& Martin, 1999; Sielezniew \& Stankiewicz, 2004; Bereczki et al., 2005; Villa et al., 2010). The species of the genus Phengaris van Eecke, 1915 have a particular life cycle: in addition to being oligophagous, they are obligatory parasites of ants of the genus Myrmica La-

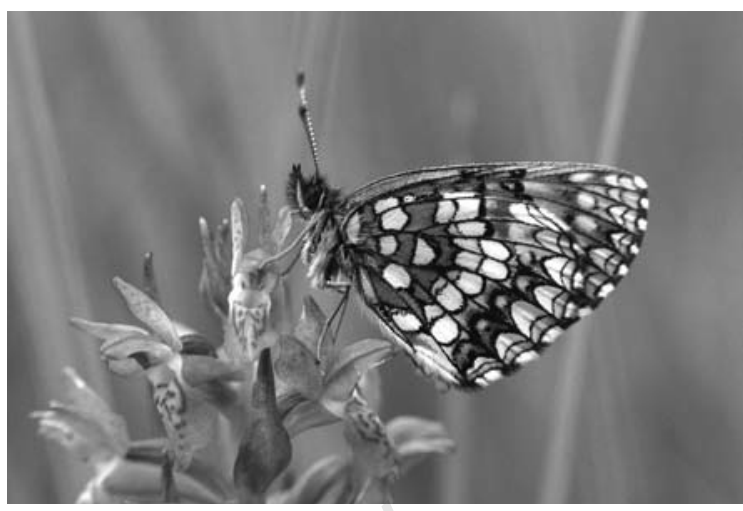

Fig. 2. Melitaea diamina (Lang, 1789). Photo by L. Maffezzoli.

treille, 1804. Phengaris alcon is associated with numerous species of the genus Myrmica, but Myrmica ruginodis Nylander, 1846, is considered the main host species (Balletto, 1993; Hellmann \& Bertaccini, 2004). The Alcon Blue is univoltine and adults fly from the middle of July to the end of August (Leigheb, 1990; Hellmann \& Bertaccini, 2004; Sielezniew \& Stankiewicz, 2004; Stankiewicz et al., 2005).

Melitaea diamina is an hygrophilous species and is present from hilly to alpine zones, below 2000 m a.s.l. (Balletto \& Kudrna, 1985; Hellmann \& Bertaccini, 2004; Villa et al., 2010). In lowland sites the species can be bivoltine, and flies in June-July and in August-September (Lepidopterologen-Arbeitsgruppe, 1991; Villa et al., 2010). The False Heath Fritillary is mainly associated with the host plant Valeriana officinalis L. (Balletto \& Kudrna, 1985; Hellmann \& Bertaccini, 2004).

FIELD WORK. To follow up the initial discoveries of $P$. alcon (22.VIII.2010) and M. diamina (24.V.2008), more data on the local populations were collected during the year 2011 by visiting a number of sites. The first individual of $P$. alcon was observed on 11.VII.2011. From 1.VIII.2011 onwards the site, which was found to host the largest population, was visited approximately every 10 days (time span 9-13 days). The last field survey was carried out on 12.IX.2011 (Fig. 4). During these "standardized surveys" two persons ( $\mathrm{SC} \& \mathrm{SH}$ ) walked in a sub-section of a larger wet meadow, which measured approxima- 


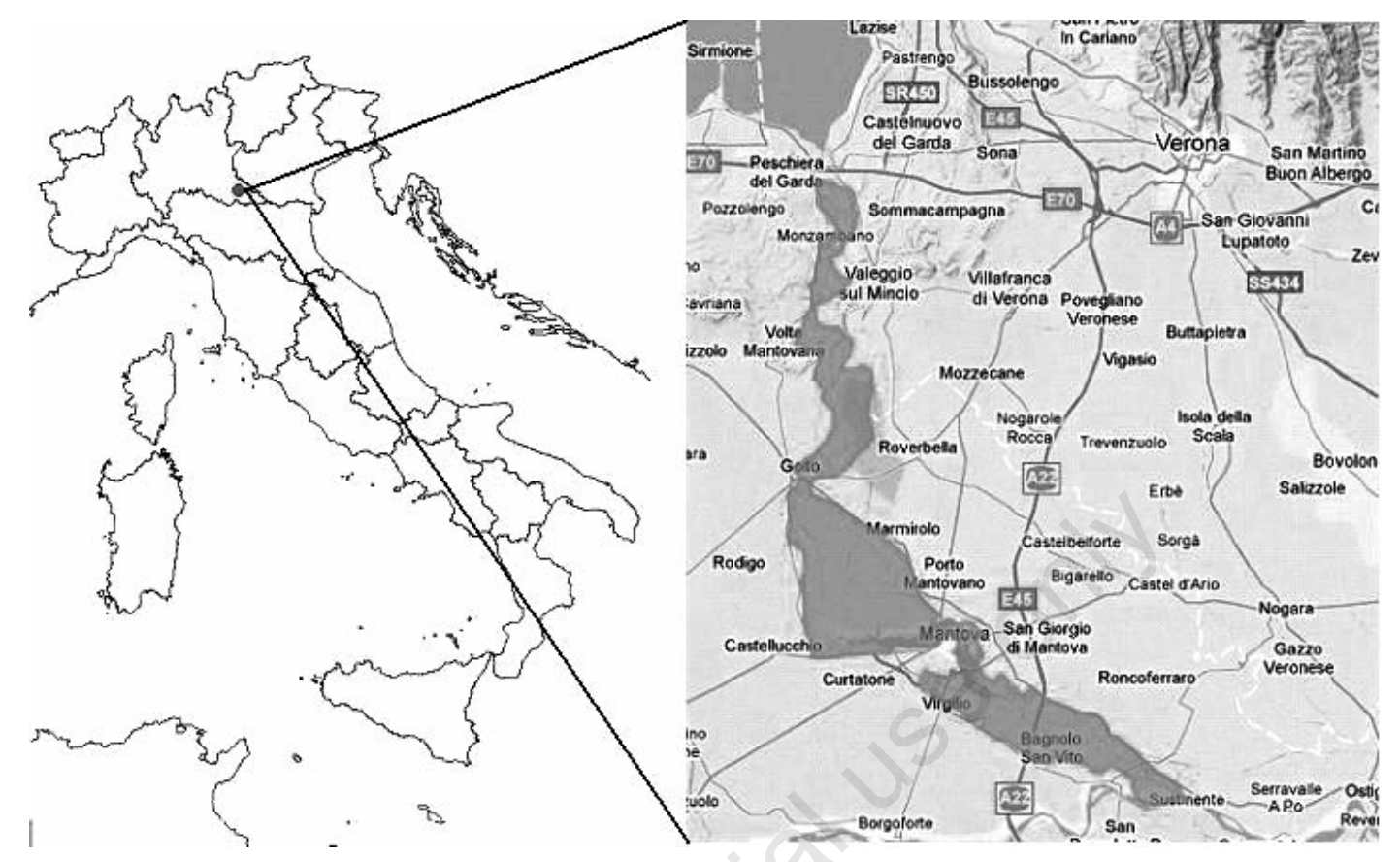

Fig. 3. Mincio Natural Park territory.

tely 3 ha, for 30 minutes, trying to cover the entire area. All adults of $P$. alcon observed were counted.

The populations of $M$. diamina were found to be much less localized and no standard survey was carried out.

Nomenclature follows Karsholt \& van Nieukerken (2004).

\section{RESULTS}

Phengaris alcon was observed in a total of 5 sites, which are all within a radius of $0.5 \mathrm{~km}$, between 11.VII. and 02.IX (Tab. 1). All observations were made in wet meadows (Tab. 3), which are potentially suitable for reproduction. Here females were observed during oviposition and eggs were recorded on many buds and flowers of Gentiana pneumonanthe. For the sites where $P$. alcon was found only municipality is reported, and UTM coordinates are truncated not to reveal the exact location of the populations.

Melitaea diamina (Lang, 1789) was observed in a total of 6 sites, which are all within a radius of 3 $\mathrm{km}$, between 15.V. and 01.VIII (Tab. 2). All obser- vations regarded single individuals and were made in wet meadows (Tab. 3), which are potentially suitable for reproduction.

\section{Discussion AND CONCLUSIONS}

BIOGEOGRAPHY. The butterfly fauna of Italy is generally well known (Balletto et al., 2005a). However, new discoveries are regularly reported, which extend the known biogeographic range of species (e.g. Sala \& Bettini, 2000; Rallo \& Uliana, 2001; Camerini \& Groppali, 2003; Pensotti, 2004; D’Amico, 2005; Negrisolo \& Uliana, 2006; Bertaccini, 2008). Therefore, on a finer scale the distribution of many Italian butterfly species has not been mapped in sufficient detail. This also applies to the Po Plain, as it is demonstrated by the two newly discovered species for the Mincio Natural Park. For P. alcon and M. diamina the closest known populations, to those reported here, are approximately $170 \mathrm{~km}$ and $50 \mathrm{~km}$ away, respectively. Phengaris alcon had never before been reported from the Po Plain and the population reported here extends the distributional area to the south (Fig. 5) and seems to 
Tab. 1. Records of Phengaris alcon ([Denis \& Schiffermüller], 1775) in the Mincio Natural Park.

\begin{tabular}{|c|c|c|c|c|c|c|}
\hline $\begin{array}{l}\text { Number } \\
\text { of individuals }\end{array}$ & Sex & $\begin{array}{c}\text { Site } \\
\text { (Tab. 3) }\end{array}$ & Date & Vidit & Legit & Collection \\
\hline uk & $\hat{o}$, q & G & 22.VIII.2010 & LM & & \\
\hline uk & $\hat{o}$, 우 & $\mathrm{H}$ & 22.VIII. 2010 & LM & & \\
\hline 1 & q & $\mathrm{E}$ & 11.VII.2011 & & $\mathrm{SC}$ & CNBFVR \\
\hline 1 & $\hat{\jmath}$ & $\mathrm{E}$ & 01.VIII.2011 & & SH & CNBFVR \\
\hline 45 & $\hat{o}$, ㅇ & $\mathrm{E}$ & 01.VIII.2011 & $\mathrm{SC}, \mathrm{SH}$ & & \\
\hline 1 & $\mathrm{uk}$ & $\mathrm{F}$ & 01.VIII.2011 & $\mathrm{SH}$ & & \\
\hline 4 & o,,+ & $\mathrm{J}$ & 01.VIII.2011 & SH & & \\
\hline$>100$ & ふ, & $\mathrm{E}$ & 11.VIII.2011 & $\mathrm{SC}, \mathrm{SH}$ & & \\
\hline 6 & $\hat{0}$, ㅇ & $\mathrm{E}$ & 24.VIII.2011 & $\mathrm{SC}, \mathrm{SH}$ & & \\
\hline 4 & $\hat{o}, q$ & $\mathrm{E}$ & 02.IX.2011 & $\mathrm{SC}, \mathrm{SH}$ & & \\
\hline
\end{tabular}

Abbreviations. Observers: LM - Lorenzo Maffezzoli, SC - Serena Corezzola, SH - Sönke Hardersen. Other abbreviations: uk unknown, CNBFVR - Centro Nazionale per la Biodiversità Forestale "Bosco Fontana" di Verona.

Tab. 2. Records of Melitaea diamina (Lang, 1789) in the Mincio Natural Park.

\begin{tabular}{|c|c|c|c|c|c|c|}
\hline $\begin{array}{l}\text { Number } \\
\text { of individuals }\end{array}$ & Sex & $\begin{array}{c}\text { Site } \\
\text { (Tab. 3) }\end{array}$ & Date & Vidit & Legit & Collection \\
\hline uk & uk & A & 24.V.2008 & LM & & \\
\hline 1 & $\hat{0}$ & $\mathrm{~B}$ & 17.VII.2008 & & $\mathrm{SH}$ & SH \\
\hline uk & uk & $\mathrm{C}$ & 15.V.2011 & LM & & \\
\hline 1 & uk & $\mathrm{D}$ & 17.V.2011 & $\mathrm{SC}$ & & \\
\hline 1 & $\widehat{\sigma}$ & $\mathrm{E}$ & 30.V.2011 & & $\mathrm{SC}$ & CNBFVR \\
\hline 1 & $\hat{0}$ & $\mathrm{D}$ & 14.VII.2011 & & $\mathrm{SC}$ & CNBFVR \\
\hline 1 & uk & $\mathrm{D}$ & 14.VII.2011 & $\mathrm{SC}$ & & \\
\hline 1 & $\hat{0}$ & $\mathrm{~F}$ & 01.VIII.2011 & & $\mathrm{SC}$ & CNBFVR \\
\hline
\end{tabular}

Abbreviations. Observers: LM - Lorenzo Maffezzoli, SC - Serena Corezzola, SH - Sönke Hardersen. Other abbreviations: uk unknown, CNBFVR - Centro Nazionale per la Biodiversità Forestale "Bosco Fontana" di Verona.

Tab. 3. Observation sites (see Tabs. 1 \& 2).

For sites where Phengaris alcon was found only the municipality is reported, and UTM coordinates are truncated to not reveal the exact location of the population of $P$. alcon.

\begin{tabular}{lccccc}
\hline Acronym & Municipality & Locality & m a.s.l. & UTM 32 T \\
\hline A & Porto Mantovano & Belvedere & 16 & 633473 & 5003788 \\
B & Mantua & Rio Freddo & 17 & 637803 & 5003127 \\
C & Porto Mantovano & Belvedere & 17 & 634453 & 5002748 \\
D & Marmirolo & Bosco Fontana & 24 & 637181 & 5006755 \\
E & Porto Mantovano & - & 16 & 633000 & 5003000 \\
F & Porto Mantovano & - & 17 & 633000 & 5003000 \\
G & Porto Mantovano & - & 17 & 633000 & 5003000 \\
H & Porto Mantovano & - & 16 & 634000 & 5003000 \\
J & Porto Mantovano & - & 16 & 634000 & 5003000 \\
\hline
\end{tabular}


be very isolated. In Northern Italy, $M$. diamina is mainly known from the Alps, however populations from the Po Plain have been reported, from the river Ticino (Ozzero, Turbigo and Vigevano, Lombardy Region) and from two sites in the Region Friuli-Venezia Giulia (Azzano Decimo and Portogruaro) (Fig. 6) (Balletto et al., 2005a). The population discovered in the Mincio Natural Park extends the known distributional area for M. diamina in Northern Italy.

FLIGHT PERIOD. For $P$. alcon the flight period coincides well with the one reported in the literature, from the middle of July to the end of August (Leigheb, 1990; Hellmann \& Bertaccini, 2004; Sielezniew \& Stankiewicz, 2004; Stankiewicz et al., 2005). The observation of 4 individuals on 02.IX.2011 extends this period to early September. The population described here was recorded 53 consecutive days, while Nowicki et al. (2005b) reported that the flight period lasted 18-36 days.

For bivoltine populations of $M$. diamina the flight periods are given as June and September (Lepidopterologen-Arbeitsgruppe, 1991) and June-July and August-September (Villa et al., 2010) For the population described here the flight periods observed were late May and middle of July to early August. This early flight period of $M$. diamina reported here might be related to the low elevation of the sites (16-24 m a.s.l.) and/or to the high summer temperatures, that can influence butterfly flight period (Balletto et al., 2009).

HABITAT AND CONSERVATION. In Italy butterflies confined to lowland grasslands have the highest extinction risk in the short term and hygrophilous species restricted to the Po Plain are among the most endangered in Italy (Balletto et al., 2009). It is in keeping that $P$. alcon is considered among the most endangered hygrophilous butterfly species in Italy. The main risk factor for this species is habitat alteration (Wyhnoff, 1998; Balletto et al., 2005b), which negatively affects the availability of the host plant Gentiana pneumonanthe, which in turn limits populations of P. alcon (Nowicki et al., 2005a). The protection of wet meadows in the Po Plain is particularly difficult as this part of Italy is the most heavily industrialized and most densely populated area of the country. The few remaining semi-natural habitats are small, fragmented and isolated, as well as under continuous human pressures (Balletto et al., 2005b). Therefore, it is of the highest importance to protect the remai-

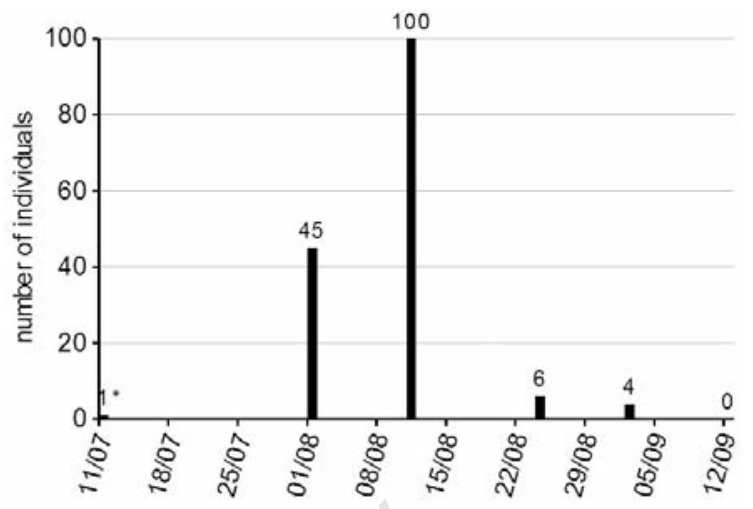

Fig. 4. The number of individuals of $P$. alcon observed during "standard counts" (see text) in an area covering approximately 3 ha. The individual reported for 11 July was counted on a much smaller sub-area $\left(1250 \mathrm{~m}^{2}\right)$.

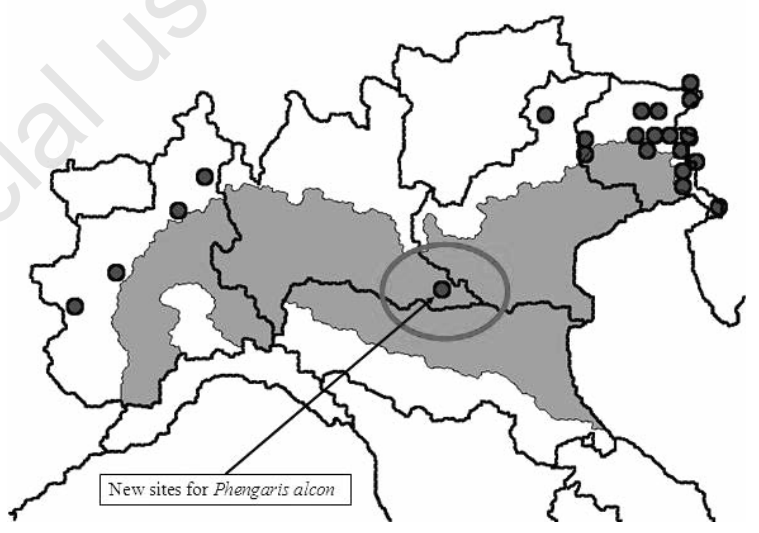

Fig. 5. P. alcon distribution (Balletto et al., 2005a) update with the new sites found in central Po Plain (grey area).

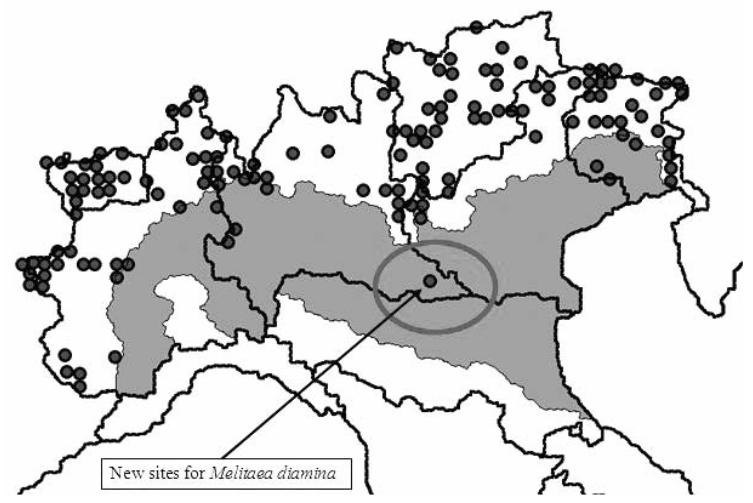

Fig. 6. M. diamina distribution (Balletto et al., 2005a) update with the new sites found in central Po Plain (grey area). 
ning wet meadows in the Mincio Natural Park and to manage these in accordance with the biology of $P$. alcon and M. diamina as the survival of these species depends on traditional agricultural activities which maintain their habitats (Wyhnoff, 1998). Currently these wet meadows are regularly mown. If this activity ceases the vegetation rapidly develop into different plant communities, which are less suitable for host ants and food plants for P. alcon (Clarke et al., 2005; Rigoni et al., 2010) and for the food plants for M. diamina. Additionally, it is important to investigate further the butterfly fauna of the Mincio Natural Park, as currently very limited knowledge about this taxon is available (Rigoni et al., 2010). The data provided for the Alcon Blue suggest that the Mincio Natural Park hosts a rather large population. However, data from only part of the suitable habitat and from a single year are not sufficient to provide a detailed analysis of the population of this rare butterfly. Similarly, the False Heath Fritillary Further is now known to be relatively widely distributed within the Natural Park. However it is necessary to learn more about local populations, before this species can be protected efficiently. Further surveys of butterflies are also important as more species of conservation concern might be present in the Mincio Natural Park.

\section{ACKNOWLEDGMENTS}

We thank the administration of the Mincio Natural Park for the permission to investigate butterflies and Elena Bontempo for correcting the English.

\section{REFERENCES}

Als T.D., Vila R., Kandul N.P., Nash D.R., Yen S.-H., Hsu Y.-F., Mignault A.A., Boomsma J.J. \& Pierce N.E., 2004 - The evolution of alternative parasitic life histories in Large Blue butterflies. Nature, 432: 386-390.

Balletto E., 1993 - Large Blues, Maculinea spp. Pp. 85-87. In: New T. R. (ed). Conservation biology of Lycaenidae (butterflies). International Union for Conservation of Nature and Natural Resources. Species Survival Commission.

Balletto E., Bonelli S. \& CAssulo L., 2005a - Insecta Lepidoptera Papilionoidea, pp 257-261. In: S. Ruffo \& F. Stoch (eds). Checklist e distribuzione della fauna italiana. Memorie del Museo Civico di Storia Naturale di Verona - 2. Serie, Sezione Scienza della Vita, 16.

Balletto E., Bonelli S. \& Cassulo L., 2005b - Mapping the Italian Butterfly Biodiversity for Conservation, pp. 71-76. In: E. Kühn, R. Feldmann, J.A. Thomas \& J. Settele (eds). Studies on the Ecology and Conservation of Butterflies in Europe. Vol. 1: General Concepts and Case Studies. Pensoft Publishers, Sofia.

Balletto E., Barbero F., Casacci L.P., Cerrato C., Patricelli D. \& Bonelli S., 2009 - L'impatto dei cambiamenti climatici sulle farfalle italiane. Studi Trentini di Scienze Naturali, 86: 111-114.

BALLETTO E. \& KudRNA O., 1985 - Some aspects of the conservation of butterflies in Italy, with recommendations for a future strategy. Bollettino della Società Entomologica Italiana, 117(1-3): 39-59.

Bereczki J., Pecsenye K., Peregovits L. \& Varga Z., 2005 - Pattern of genetic differentiation in the Maculinea alcon species group (Lepidoptera, Lycaenidae) in Central Europe. Journal of Zoological Systematics and Evolutionary Research, 43(2): $157-165$.

BERTACCINI E., 2008. Note integrative sulla Macrolepidotterofauna Romagnola (Insecta Lepidoptera Rhopalocera, Heterocera). Quaderno di Studi e Notizie di Storia Naturale della Romagna, 26: 91-128.

CAmerini G. \& Groppali R., 2003 - Nuove segnalazioni di Lycaena dispar (Haworth) in pianura padana (Lepidoptera Rhopalocera). Pianura. Scienze e storia dell'ambiente Padano, 17: 142-145.

Clarke R.T., Mouquet N., Thomas J.A., Hochberg M.E., Elmes G.W., Tesar D., Singer A. \& Hale J., 2005 - Modelling the local population dynamics of Maculinea and their spatial interactions with their larval foodplant and Myrmica ant species, pp. 115 - 119. In: J. Settele, E. Kühn \& J.A. Thomas (eds). Studies on the Ecology and Conservation of Butterflies in Europe. Vol. 2: Species Ecology along a European Gradient: Maculinea Butterflies as a Model. Pensoft Publishers, Sofia.

D’Amico G., 2005 - Segnalazione di alcune specie di macrolepidotteri (Lepidoptera) nuovi per il Parco della Valle del Ticino. Pianura. Scienze e storia dell'ambiente Padano, 19: 149-154.

Descimon H. \& Mallet J., 2009 - Bad species, pp. 219 - 249. In: J. Settele, T. Shreeve, M. Konvička \& H.V. Dyck (eds). Ecology of Butterflies in Europe. Cambridge University Press, Cambridge.

Hellmann F. \& Bertaccini E., 2004 - I Macrolepidotteri della Valle di Susa. Italia Nord-occidentale (Alpi Cozie-Graie). 
Regione Piemonte, Museo Regionale di Scienze Naturali, Monografie XL, 389 pp., 16 Tavv.

Karsholt O. \& van Nieukerken E.J., 2004 - Fauna Europaea: Papilionoidea. Available at http://www.faunaeur.org [accessed December 2011 as version 2.4 of 27 January 2011].

KÜER A. \& FARTMANN T., 2005 - Prominent shoots are preferred: microhabitat preferences of Maculinea alcon ([Denis \& Schiffermüller], 1775) in Northern Germany (Lycaenidae). Nota Lepidopterologica, 27 (4): 309-319.

LAFranchis T., 2004 - Butterflies of Europe. Diatheo, Paris, 351 pp.

LeIGHeb G., 1990 - Una colonia relitta di Maculinea alcon Denis Schiffermüller in Piemonte (Lepidoptera, Lycaenidae). Rivista Piemontese di Storia Naturale. Carmagnola, 11: 129-134.

Lepidopterologen Arbeitsgruppe, 1991 - Tagfalter und ihre Lebensräume:Arten, Gefahrung, Schutz. Schweitzerischer Bund für Naturschutz. 3. Auflage, Basel, 516 pp.

Munguira M.L. \& Martin J., 1999 - Action plan for the Maculinea butterflies in Europe. Conseil de l'Europe, Strasbourg, 64 pp.

Negrisolo E. \& Uliana M., 2006 - Nuovi dati sui Ropaloceri dei Colli Euganei. Lavori Società Veneziana di Scienze Naturali, 31:116-117.

Nowicki P., Pępkowska A., KudŁek J., Skórka P., Witek M. \& Woyciechowski M., 2005a - Landscape scale research in butterfly population ecology - Maculinea case study, Pp. 140-143. In: J. Settele, E. Kühn \& J.A. Thomas (eds). Studies on the Ecology and Conservation of Butterflies in Europe. Vol. 2: Species Ecology along a European Gradient: Maculinea Butterflies as a Model. Pensoft Publishers, Sofia.

Nowicki P., Settele J., Thomas J.A.\& Woyciechowski M., 2005b - A review of population structure of Maculinea butterflies, pp. 144-149. In: J. Settele, E. Kühn \& J.A. Thomas (eds). Studies on the Ecology and Conservation of Butterflies in Europe. Vol. 2: Species Ecology along a European Gradient: Maculinea Butterflies as a Model. Pensoft Publishers, Sofia.

Pecsenye K., Bereczi J., Tihanyi B., Tóth A., Peregovits L. \& Varga Z., 2007 - Genetic differentiation among the Maculinea species (Lepidoptera: Lycaenidae) in eastern Central Europe. Biological Journal of the Linnean Society, 91: 11-21.

Pensotti C.S.M., 2004 - Nuovo contributo alla conoscenza delle Farfalle diurne (Insecta, Lepidoptera, Hesperioidea e Papilionoidea) della provincia di Sondrio (Lombardia, Italia Settentrionale). Il Naturalista Valtellinese - Atti del Museo Civico di Storia Naturale di Morbegno, 15: 29-59.

Rallo G. \& Uliana M., 2001 - Note su alcuni Lepidoptera di Valle Averto in Laguna di Venezia e dell'entroterra veneziano. Ricerche scientifiche nella Riserva naturale del W.W.F. di Valle dell'Averto. Bollettino Museo Civico di Storia Naturale di Venezia, 52: 103-112.

Rigoni P., Martignoni C., Corazza M., Maffezzoli L., Messori L. \& Fabbri R., 2010 - Piano di Gestione del SIC IT20B0017 "Ansa e Valli del Mincio" e della ZPS IT20B0009 "Valli del Mincio".

SALA G. \& Bettini R., 2000 - Contributo alla conoscenza della lepidotterofauna (Lepidoptera, Hesperioidea e Papilionidea del Compensario Gardesano e di altri biotopi del bresciano con la prima segnalazione di Brenthis ino per la provincia di Brescia. Natura Bresciana, Annuario del Museo Civico di Storia Naturale di Brescia, 32:77-88.

Sielezniew M. \& StAnKIEwicz A.M., 2004 - Gentiana cruciata as an additional host plant of Maculinea alcon on a site in eastern Poland (Lycaenidae). Nota Lepideptorologica, 27 (1): 91-93.

ŚLiwińska E.B., Nowicki P., NASh D.R., Witek M., Settele J. \& Woyciechowski M., 2006 - Morphology of caterpillars and pupae of European Maculinea species (Lepidoptera: Lycaenidae) with an identification table. Entomologica Fennica, 17: $351-358$.

StAnkiewicz A.M., Sielezniew M. \& BuszKo J., 2005 - Maculinea alcon and M. rebeli in Poland: distribution, habitats, host ant specificity and parasitoids, pp. 90-93. In: J. Settele, E. Kühn \& J.A. Thomas (eds). Studies on the Ecology and Conservation of Butterflies in Europe. Vol. 2: Species Ecology along a European Gradient: Maculinea Butterflies as a Model. Pensoft Publishers, Sofia.

Tolman T. \& Lewington R., 2009 - Collins Butterfly Guide. The most complete guide to the Butterflies of Britain and Europe. Harpes Collins Publishers, London. 384 pp.

Van Swaay C., Cuttelod A., Collins S., Maes D., LóPez Munguira M., Šašić M., Settele J., Verovnik R., Verstrael T., WArren M., Wiemers M. \& Wynhoff I., 2010 - European Red List of Butterfies. Luxembourg: Publications Office of the European Union, 47 pp. 
VARGA-Sipos J. \& VARGA Z., 2005 - Maculinea habitats: diversity of vegetation, composition and cenological relegation, pp. 45-50. In: J. Settele, E. Kühn \& J.A. Thomas (eds). Studies on the Ecology and Conservation of Butterflies in Europe. Vol. 2: Species Ecology along a European Gradient: Maculinea Butterflies as a Model. Pensoft Publishers, Sofia.

Villa R., Pellecchia M. \& Pesce G.B., 2010 - Farfalle d'Italia. Istituto per i Beni Artistici, Culturali e Naturali della Regione Emilia Romagna. Editrice Compositore, 375 pp.

Wynhoff I., 1998 - The recent distribution of the European Maculinea species. - Journal of Insect Conservation, 2: 15-27.

Authors' addresses:

S. Corezzola, Corpo Forestale dello Stato, Centro Nazionale per lo Studio e la Conservazione della Biodiversità Forestale "Bosco Fontana" di Verona, Strada Mantova, 29, I-46045 MARMIROLO (MN). corezzola.serena@gmail.com S. Hardersen, Corpo Forestale dello Stato, Centro Nazionale per lo Studio e la Conservazione della Biodiversità Forestale "Bosco Fontana” di Verona, Strada Mantova, 29, I-46045 MARMIROLO (MN). s.hardersen@gmail.com L. Maffezzoli, Viale Piave, 7, 46100 Mantova.1maffezzoli@libero.it 